\title{
PENGARUH JUS SEMANGKA TERHADAP MAP (MEAN ARTERI PRESSURE) PADA LANSIA PENDERITA HIPERTENSI DI WILAYAH KERJA PUSKESMAS BINJAI ESTATE
}

\author{
Lasma Rina Efrina Sinurat, Marthalena Simamora \\ Program Studi Ners Fakultas Farmasi dan Ilmu Kesehatan, Universitas Sari Mutiara Indonesia \\ E-mail : lasma_rina13@yahoo.com \\ Program Studi Ners Fakultas Farmasi dan Ilmu Kesehatan, Universitas Sari Mutiara Indonesia \\ E-mail : martha_march88@ymail.com
}

\begin{abstract}
Changes in modern lifestyles, such as smoking, drinking alcohol, unbalanced eating patterns and lack of physical activity can trigger an increased incidence of hypertension. One of the hypertension therapies that utilize herbal plants is watermelon. The study aims to determine the effect of watermelon juice on Mean Arterial Pressure (MAP) in elderly people with hypertension in the Binjai Estate Health Center. This type of research is quasy-experimental one group pre-post test. The population used was all elderly with hypertension as many as 76 people. The samples in this study were 28 people using purposive sampling technique. Data analysis uses paired T-test (TDependent). The results showed that there was an influence of giving watermelon juice to Mean Arterial Pressure (MAP) in elderly patients with hypertension with a p-value of 0,000 with a MAP value before being given watermelon juice therapy $119.304 \mathrm{mmHg}$ and the value of MAP after watermelon juice therapy was $103.039 \mathrm{mmHg}$. It is recommended that patients be expected to continue to consume watermelon juice more routinely for 7 days weighing 250 grams / day, but need to control blood pressure so that hypotension does not occur suddenly and need to improve good lifestyle.
\end{abstract}

Keywords : Watermelon Juice, Mean Arteri Pressure, Hypertension

\begin{abstract}
Abstrak
Perubahan gaya hidup modern, seperti merokok, minuman alkohol, pola makan yang tidak seimbang dan kurangnya aktivitas fisik dapat memicu meningkatnya angka kejadian penyakit hipertensi. Salah satu terapi hipertensi yang memanfaatkan tanaman herbal yaitu semangka. Penelitian bertujuan untuk mengetahui pengaruh pemberian jus semangka terhadap Mean Arteri Pressure (MAP) pada lansia penderita hipertensi di Wilayah Kerja Puskesmas Binjai Estate. Jenis penelitian quasy-eksperiment one group pre-post test. Populasi yang digunakan adalah seluruh lansia penderita hipertensi sebanyak 76 orang. Sampel dalam penelitian ini sebanyak 28 orang dengan menggunakan teknik purposive sampling. Analisa data menggunakan uji paired T-test ( $T$ Dependent). Hasil penelitian menunjukkan bahwa ada pengaruh pemberian jus semangka terhadap Mean Arteri Pressure (MAP) pada lansia penderita hipertensi dengan nilai p-value 0,000 dengan nilai MAP sebelum diberikan terapi jus semangka $119,304 \mathrm{mmHg}$ dan nilai MAP sesudah diberikan terapi jus semangka $103,039 \mathrm{mmHg}$. Disarankan bagi pasien diharapkan dapat melanjutkan untuk mengkonsumsi jus semangka lebih rutin selama 7 hari dengan berat 250 gram/hari, akan tetapi perlu mengontrol tekanan darah agar tidak terjadi hipotensi secara mendadak dan perlu memperbaiki pola hidup yang baik.
\end{abstract}

Kata Kunci : Jus Semangka, Mean Arteri Pressure (MAP), Hipertensi 


\section{PENDAHULUAN}

Hipertensi merupakan masalah kesehatan yang umum terjadi di negara berkembang dan negara maju. Perubahan gaya hidup modern, seperti merokok, minuman alkohol, pola makan yang tidak seimbang dan kurangnya aktivitas fisik dapat memicu meningkatnya angka kejadian penyakit hipertensi (Martha, 2012 dalam Komaling 2013). Hal ini dapat dibuktikan dengan semakin hari penderita hipertensi semakin meningkat. Namun dari jumlah total penderita hipertensi tersebut, baru sekitar 50 persen yang terdeteksi. Dan diantara penderita tersebut hanya setengahnya yang berobat secara teratur (Suiraoka, 2016).

Menurut World Health Organization (WHO, 2013), sekitar 1 milyar penduduk di seluruh dunia menderita hipertensi dimana dua pertiganya terdapat di negara- negara berkembang. Hipertensi menyebabkan 8 juta penduduk di seluruh dunia meninggal setiap tahunnya, dimana hampir 1,5 juta penduduk diantaranya terdapat di kawasan Asia tenggara. WHO mencatat pada tahun 2012 terdapat 839 juta kasus penderita hipertensi dan diperkirakan akan meningkat menjadi 1,15 milyar pada tahun 2025 atau sekitar $29 \%$ dari total penduduk dunia, dimana penderitanya lebih banyak pada wanita (30\%) dibandingkan pria (29\%) (Triyanto, 2014).

Sementara data dari National Health Documentation (NHD) di Amerika Serikat menemukan prevalensi hipertensi $15-27 \%$ pada orang-orang berusia 65 tahun keatas. Pada orang-orang negro angka ini lebih tinggi yaitu 26-29\%. Dari survei hipertensi yang telah diadakan oleh Dinkes di Indonesia selama ini, prevalensi hipertensi pada orangorang Indonesia dewasa berkisar 5-10\% dan angka ini akan menjadi lebih dari $20 \%$ pada kelompok umur 50 tahun keatas (Maidelwita, 2011).

Menurut Riset Kesehatan Dasar (RISKESDAS) tahun 2013, prevalensi hipertensi di Indonesia mencapai $25,8 \%$, jika saat ini penduduk Indonesia 252.124.458 jiwa maka terdapat 65.048.110 jiwa yang menderita hipertensi. Prevalensi ini semakin bertambah seiring dengan bertambahnya usia. Penyakit ini menjadi salah satu masalah utama dalam kesehatan masyarakat di Indonesia maupun dunia. Diperkirakan sekitar 80\% kenaikan kasus hipertensi terutama terjadi dinegara berkembang pada tahun 2025 dari jumlah total 639 juta kasus di tahun 2000. Jumlah diperkirakan meningkat menjadi 1.15 miliar kasus di tahun 2025 . Prediksi ini didasarkan pada angka penderita hipertensi dan pertambahan saat ini (Ardiansyah, 2012).

Secara alamiah, fungsi fisiologis dalam tubuh lansia menurun seiring pertambahan usianya. Penurunan fungsi ini tentunya akan menurunkan kemampuan lansia untuk menanggapi datangnya rangsangan baik dari luar tubuh maupun dari dalam tubuh lansia itu sendiri. Satu persatu fungsi organ akan mulai berkurang, kemampuan jaringan untuk mempengaruhi diri secara perlahan-lahan dan mempertahankan infeksi dan memperbaiki kerusakan yang diderita akan semakin berkurang. Semakin tua seseorang semakin rentan terhadap berbagai penyakit begitu juga semakin tua seseorang semakin sulit untuk penyembuhan yang lebih cepat, ini disebabkan oleh respon organ terhadap obat yang masuk kedalam tubuh responnya pun lebih lama (Fatmah, 2010 dalam Fridalni dan Sapardi, 2013).

Seseorang dapat mengidap hipertensi selama bertahun tanpa menyadari sampai terjadi kerusakan organ vital yang cukup berat dan berisiko kematian (Kowalksi, 2010 dalam Suwandi, 2013). Hipertensi menjadi masalah pada lansia karena sering ditemukan menjadi faktor utama penyebab jantung dan penyakit koroner. Lebih dari setengah kematian lansia disebabkan oleh penyakit jantung dan hipertensi (Nugroho, 2008 dalam Suwandi, 2013).

Penyakit hipertensi bisa dikontrol dengan selalu mengkonsumsi obat anti hipertensi dan selalu mengontrol keadaan tekanan darah. Penderita tekanan darah tinggi juga bisa mengontrol tekanan darah dengan cara menghindari makanan yang tinggi kolesterol dan banyak kandungan lemak. 
Pengobatan hipertensi dikombinasikan dengan berbagai komplek obat diuretic seperti hydrochlorothiazide dan lasix obat obat tersebut merupakan golongan obat yang sangat merangsang pengeluaran cairan tubuh melalui urin. Beta karoten, kalium dan potassium yang berfungsi untuk mentralisirkan tekanan darah. Selain pengobatan secara rutin, pengkonsumsian obat anti hipertensi, penyakit tekanan darah tinggi juga bisa di obati dengan obat tradisional atau herbal (Arturo, 2012 dalam Fridalni dan Sapardi, 2013).

Salah satunya untuk terapi hipertensi masyarakat sudah banyak memanfaatkan tanaman herbal (non farmakologis), seperti timun, bawang putih, labu siam, seledri, semangka, daun salam dan masih banyak buah-buahan atau sayuran lain yang bisa digunakan untuk pengobatan herbal (Arturo, 2012).

Salah satu buah-buahan yang dapat menurunkan tekanan darah adalah semangka. Karena kandungan yang ada dalam obat anti hipertensi tersebut ada beberapa yang kita temui dalam semangka yaitu potassium, betakaroten dan kalium. Kalium menyebabkan vasodilatasi sehingga terjadi penurunan resistensi perifer dan meningkatkan curah jantung. Buah semangka memiliki kandungan kalium tinggi yang bisa menetralisir tekanan darah serta dapat menguatkan kerja jantung (Suwarto, 2010).

Semangka sangat kaya akan kandungan air, asam amino, L-arginine dapat menjaga tekanan darah yang sehat. Unsur air dan kalium yang ada dalam semangka dapat menetralkan tekanan darah dan menjaga keseimbangan tubuh. Semangka tidak memiliki efek samping untuk tubuh kita, mudah didapat dan harganya pun terjangkau untuk semua kalangan (Nisa, 2012).

Hasil penelitian Tuty Roida Pardede dan Sri Muftri (2011) menunjukkan ada perbedaan kadar kalium semangka kuning dan merah baik yang berbiji maupun tanpa biji. Berdasarkan uji spektrofotometri terlihat bahwa semangka kuning berbiji memilki kandungan kalium yang lebih tinggi dibanding dengan semangka merah, yaitu $114 \mathrm{mg} / 100 \mathrm{~g}$.

Dari data studi penelitian sebelumnya, yang dilakukan oleh Putri tahun 2007, diketahui bahwa pemberian jus semangka pada penderita tekanan darah tinggi yang dilakukan selama 7 hari dapat menurunkan tekanan darah secara sistematis dan mengurangi efek samping yang ditimbulkan oleh obat anti hipertensi.

Berdasarkan hasil penelitian Caturwati, (2013) terlihat bahwa 7 hari setelah pemberian jus semangka kuning seberat 250 gram 6 orang mengalami penurunan tekanan darah sebesar 5 hingga 10 mmHg. Penelitian Ina Nurlina (2011) juga mengungkapkan hal yang sama, bahwa jus semangka kuning terbukti signifikan menurunkan tekanan darah sistolik dan diastolik normal pada wanita dewasa.

Penelitian Figueroa dalam Nisa, (2012) mengemukakan, bahwa kandungan asam amino semangka mampu meningkatkan fungsi arteri dan menurunkan tekanan darah pada aorta. Semangka dapat menurunkan tekanan darah tinggi karena mengandung potassium, vitamin $\mathrm{C}$, karbohidrat, likopen yang berfungsi untuk meningkatkan kerja jantung dan sitrulin yang mampu mendorong aliran darah ke seluruh bagian tubuh serta memberikan efek arfosidiak.

Hasil penelitian Irma tahun 2009 yang meneliti tentang pengaruh buah semangka (Citrullus vulgaris Schard Fructus) terhadap tekanan darah normal lakilaki dewasa Bandung Universitas Kristen Maranatha, menunjukkan bahwa pemberian 250 gram jus buah semangka dapat menurunkan tekanan darah dari 105,83/68,05 $\mathrm{mmHg}$ menjadi 100,65/64,93 mmHg. Hasil tersebut dianalisis dengan t-test dengan tingkat kemaknaan 0.05. Pengukuran tekanan darah sistol dan diastol dilakukan dengan cara auskultasi pada posisi duduk.

Berdasarkan hasil survei yang dilakukan di Puskesmas Binjai Estate bahwa jumlah kunjungan lansia penderita hipertensi setiap tahunnnya terjadi peningkatan. Dari hasil survei dengan wawancara kepada beberapa lansia didapatkan bahwa belum 
pernah diberikan terapi jenis nonfarmokologi untuk menurunkan tekanan darah dengan jus semangka.

\section{METODE PENELITIAN}

Penelitian ini menggunakan desain penelitian eksperimen semu (quasyeksperimen), dengan menggunakan desain penelitian one group pre-post test maksudnya adalah pengukuran yang dilakukan 2 kali dengan cara memberikan pre test (pengamatan awal) terlebih dahulu sebelum perlakuan dan post test (pengamatan kedua) setelah perlakuan. (Sastroasmoro \& Ismail, 2016).

\section{Skema Rancangan Penelitian}

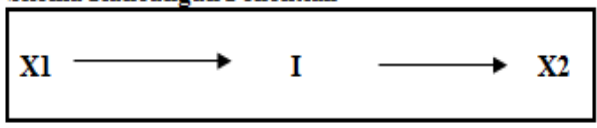

Keterangan:

$\begin{array}{ll}\text { X1 } & \text { : Pengukuran MAP sebelum dilakukan perlakuan } \\ \text { I } & \text { : Pemberian Jus semangka } \\ \text { X2 } & \text { : Pengukuran MAP sesudah dilakukan perlakuan }\end{array}$

Populasi dalam penelitian ini adalah seluruh lansia penderita hipertensi di Wilayah Kerja Puskesmas Binjai Estate yang berjumlah 76 orang. Sampel dalam penelitian ini adalah seluruh penderita hipertensi yang di wilayah kerja Puskesmas Binjai Estate yang di ambil dengan menggunakan teknik purposive sampling, yaitu pengambilan sampel didasarkan pada suatu pertimbanganpertimbangan tertentu dalam pengambilan sampel yaitu berjumlah 28 orang. Dengan kriteria inklusi sebagai berikut:

a. Usia $>55$ tahun.

b. Tekanan darah sistolik $>140 \mathrm{mmHg}$ dan diastolik >90 mmHg.

c. Lansia penderita hipertensi yang bersedia menjadi responden.

d. Sedang tidak minum obat hipertensi.

Kriteria Ekslusi:

a. Penderita hipertensi berat.

b. Lansia penderita hipertensi yang tidak bersedia menjadi responden.

Instrumen pengumpulan data dalam penelitian ini yaitu tensi meter digital dalam satuan $\mathrm{mmHg}$, SOP pemberian jus, dan lembar observasi dalam hal pengukuran MAP.

Prosedur Pengumpulan Data

Tahap Persiapan

Responden yang dipilih berdasarkan kriteria inklusi dan bersedia selanjutnya diminta untuk menandatangani lembar informed consent.

Tahap Pelaksanaan

1. Pada hari pertama dilakukan pengukuran tekanan darah menggunakan tensi meter digital kepada responden sebanyak 28 orang.

2. Responden duduk tenang dan rileks selama 2 menit.

3. Kemudian diberikan buah semangka yang diblender dan dijadikan jus sebanyak 250 gram atau setara $150 \mathrm{ml}$.

4. Pemberiannya dilakukan selama 7 hari berturut-turut pada siang hari.

Evaluasi Akhir

1. Setelah 7 hari maka di lakukan kembali pengukuran tekanan darah (sistolik dan diastolik) menggunakan tensi meter digital post intervensi.

2. Hasil dituliskan di lembar observasi lalu di hitung rata-ratanya menggunakan rumus :

$$
M A P=\frac{\text { sistole }+(2 . \text { diastole })}{3}
$$

\section{Analisa Univariat}

Dilakukan untuk mendapatkan gambaran distribusi subyek penelitian serta menggambarkan variabel bebas yaitu pengaruh jus semangka dan variabel terikat yaitu MAP lansia penderita hipertensi.

\section{Analisa Bivariat}

Dilakukan menggunakan Uji Paired T-Test (T-Dependent). Sebelum dilakukan uji Paired T-test (T-Dependent) dilakukan Uji Normalitas data dengan menggunakan $U j i$ Shapiro-Wilk yang dilakukan untuk melihat apakah data berdistribusi normal atau tidak. 
Selanjutnya dilakukan Uji Paired T-Test. Untuk menyimpulkan apakah ada pengaruh pemberian jus semangka terhadap perubahan Mean Arteri Pressure di Wilayah Kerja Puskesmas Binjai Estate.

\section{HASIL PENELITIAN}

A. Analisa Univariat

\section{Karakteristik Responden}

Tabel 4.1 Distribusi Frekuensi Karakteristik Penderita Hipertensi di Wilayah Kerja Puskesmas Binjai Estate $(\mathrm{n}=28)$

\begin{tabular}{lcc}
\hline Karakteristik Responden & $\mathbf{n}$ & $\mathbf{\%}$ \\
\hline Jenis Kelamin & & \\
Laki-laki & 10 & 35,7 \\
Perempuan & 18 & 64,3 \\
\hline Umur & & \\
50-60 Tahun & 2 & 7,1 \\
$>60$ Tahun & 26 & 92,9 \\
\hline
\end{tabular}

Berdasarkan tabel 4.1 dapat dilihat bahwa umur responden mayoritas > 60 tahun yaitu sabanyak 26 orang $(92,9 \%)$, jenis kelamin mayoritas perempuan sebanyak 18 orang $(64,3 \%)$.

2. Rata-rata Mean Arteri Pressure (MAP) Pada Penderita Hipertensi Sebelum dan Sesudah Diberikan Jus Semangka di Wilayah Kerja Puskesmas Estate

Tabel 4.2 Distribusi Frekuensi Rata-rata Mean Arteri Pressure (MAP) Pada Penderita Hipertensi Sebelum dan Sesudah Diberikan Jus Semangka di Wilayah Kerja Puskesmas Estate $(\mathrm{n}=28)$

\begin{tabular}{lcccc}
\hline MAP & Mean & Median & $\begin{array}{c}\text { Std. } \\
\text { Deviasi }\end{array}$ & Min-Max \\
\hline $\begin{array}{l}\text { Sebelum } \\
\text { Intervensi }\end{array}$ & 119,304 & 118,150 & 6,7573 & $109-131$ \\
\hline $\begin{array}{l}\text { Sesudah } \\
\text { Intervensi }\end{array}$ & 103,039 & 100.950 & 7,5977 & $91,3-119$ \\
\hline
\end{tabular}

Berdasarkan tabel 4.2 dapat diketahui bahwa rata-rata Mean Arteri Pressure (MAP) sebelum diberikan jus semangka adalah 119,304 mmHg, median 118,150 mmHg, Std. Deviasi 6,7573, nilai minimum $109 \mathrm{mmHg}$ dan nilai maximum $131 \mathrm{mmHg}$. Sedangkan hasil rata-rata Mean Arteri Pressure (MAP) sesudah diberikan jus semangka adalah $103,039 \mathrm{mmHg}$, median 100,950 mmHg, Std. Deviasi 7,5977, nilai minimum $91,3 \mathrm{mmHg}$ dan nilai maximum $119 \mathrm{mmHg}$.

\section{B. Analisa Bivariat \\ 1. Uji Normalitas Data}

Tabel 4.3 Hasil Uji Normalitas Berdasarkan Hasil Pengukuran Mean Arteri Pressure (MAP) Sebelum dan Sesudah Diberikan Jus Semangka di Wilayah Kerja

Puskesmas Binjai Estate $(\mathrm{n}=28)$

\begin{tabular}{cccc}
\hline \multirow{2}{*}{ MAP } & \multicolumn{3}{c}{ Shapiro-Wilk } \\
\cline { 2 - 4 } & Statistik & df & Sig. \\
\hline $\begin{array}{c}\text { Sebelum Pembenan } \\
\text { Jus Semangka }\end{array}$ & .940 & 28 & .112 \\
\hline $\begin{array}{c}\text { Sesudah Pemberian } \\
\text { Jus Semangka }\end{array}$ & .950 & 28 & .200 \\
\hline
\end{tabular}

Berdasarkan tabel 4.3 uji normalitas di atas, dapat diketahui bahwa Mean Arteri Pressure (MAP) pretest jus semangka berdistribusi normal dengan nilai signifikan 0,112 ( $>0,05)$ sedangkan Mean Arteri Pressure (MAP) post test jus semangka berdistribusi normal dengan nilai signifikan 0,200 ( $p>0,05)$.

\section{PEMBAHASAN}

a. Mean Arteri Pressure (MAP) Pada Tekanan Darah Lansia Penderita Hipertensi sebelum diberikan terapi Jus Semangka di Wilayah Kerja Puskesmas Binjai Estate

Dari hasil penelitian yang didapatkan Mean Arteri Pressure (MAP) sebelum diberikan jus semangka adalah 119,304 $\mathrm{mmHg}$, median $118,150 \mathrm{mmHg}$, Standar Deviasi 6,7573 nilai minimum $109 \mathrm{mmHg}$ dan nilai maximum $131 \mathrm{mmHg}$. Hipertensi secara umum disebabkan oleh pola hidup yang kurang baik diantaranya konsumsi garam yang berlebihan karena garam dapat meningkatkan tekanan darah dengan cepat pada beberapa orang, khususnya bagi 
penderita diabetes, penderita hipertensi ringan, orang dengan usia tua, dan mereka yang berkulit hitam. Kandungan lemak yang berlebih dalam darah dapat menyebabkan timbunan kolesterol pada dinding pembuluh darah hal ini dapat membuat pembuluh darah menyempit dan akibatnya tekanan darah akan meningkat (Elisa, 2012).

Perubahan struktural dan fungsional pada sistem pembuluh darah perifer bertanggung jawab pada perubahan tekanan darah yang terjadi pada lanjut usia. Perubahan tersebut meliputi aterosklerosis, hilangnya elastisitas jaringan ikat, dan penurunan dalam relaksasi otot polos pembuluh darah, yang pada gilirannya menurunkan kemampuan distensi dan daya regang pembuluh darah. Konsekuensinya, aorta dan arteri besar.

\section{b. Mean Arteri Pressure (MAP) Pada Tekanan Darah Lansia Penderita Hipertensi sesudah diberikan terapi Jus Semngka di Wilayah Kerja Puskesmas Binjai Estate}

Dari hasil penelitian yang dilakukan Mean Arteri Pressure (MAP) sesudah diberikan jus semangka adalah 103,039 $\mathrm{mmHg}$, median 100,950 $\mathrm{mmHg}$, Std. Deviasi 7,5977 nilai minimum $91,3 \mathrm{mmHg}$ dan nilai maximum $119 \mathrm{mmHg}$. Berdasarkan hasil tersebut artinya bahwa penurunan Mean Arterial Pressure (MAP) dipengaruhi oleh penderita mendapat terapi jus semangka. Hal ini dikarenakan adanya hubungan terbalik antara kalium dan natrium. Teori mengemukakan bahwa tekanan darah berhubungan negatif dengan asupan kalium melalui hubungan fisiologisnya yang resiprokal dengan natrium (Guyton dalam Mariani, 2007).

Peranan kalium dalam mekanisme penurunan tekanan darah meskipun belum begitu jelas tetapi kalium menyebabkan vasodilatasi sehingga terjadi penurunan resistensi perifer. Selain itu kalium menghambat proses konversi pelepasan renin menjadi renin-angiotensin sehingga tidak terjadi peningkatan tekanan darah. Kalium berfungsi sebagai natriuretik, yaitu menyebabkan pengeluaran natrium dan cairan meningkat (Guyton dalam Mariani, 2007).

Sebagai langkah antisipasi untuk menurunkan tekanan darah adalah menjalankan pola makan sehat dan pola hidup sehat. Pola makan yang sehat dengan cara pengaturan menu bagi penderita hipertensi dapat dilakukan dengan cara diet rendah garam seperti kurangi makanan kaleng atau makanan yang sudah diproses dengan kandungan garam yang tinggi, diet rendah kolesterol dan lemak terbatas, makanan berlemak jenis ikan yang banyak mengandung lemak seperti ikan salmon, daging, jeroan, kacang-kacangan dan sarden, diet tinggi serat yang di anjurkan bagi penderita hipertensi adalah sayuran dan buah-buahan karena kandungan serat dan vitamin $\mathrm{C}$ dapat membantu menurunkan tekanan darah tinggi juga berfungsi untuk membantu menyerap lemak dan kandungan seratnya membantu dalam poses pencernaan makanan, dan diet rendah energi bagi mereka yang kegemukan, kurangi konsumsi alkohol berlebih karena terdapat hubungan linier antara konsumsi alkohol dengan tingkat tekanan darah dan prevelensi hipertensi pada masyarakat, dan kurangi konsumsi rokok.

Selain pola makan sehat pola hidup yang sehat juga sangat penting karena pola hidup sehat akan membuat kita sehat secara keseluruhan. Pola hidup yang harus dijalani oleh penderita hipertensi adalah dengan melakukan olahraga ringan seperti jalan kaki, renang, lari santai secara teratur, berhenti merokok, juga berperan besar untuk mengurangi hipertensi, mengendalikan kadar kolesterol, dan menurunkan berat badan bagi yang obesitas (Susilo, 2011).

Semangka dapat menurunkan tekanan darah tinggi karena mengandung postasium. Selain itu, semangka mengandung vitamin B, kaya serat, sitrulin mampu mendorong aliran darah keseluruh tubuh, mengkonsumsi semangka sangat baik untuk penderita hipertensi karena semangka bersifat diuretik yaitu semangka dapat merangsang pengeluaran urine. Hal ini sangat baik bagi tubuh karena, racun dan kadar natrium 
berlebih yang ada dalam tubuh dibuang melalui buang air kecil atau urin (Suriana dan Shobariani, 2013).

Gustomi, (2014) pengkonsumsian jus semangka secara teratur dapat menurunkan tekanan darah, ini terbukti dari penurunan tekanan darah responden yang mengkonsumsi jus semangka selama 7 hari berturut-turut. Pada hari pertama penelitian sebelum pemberian jus semangka didapatkan tekanan darah responden rata-rata berada diatas normal. Setelah pemberian jus semangka secara teratur didapatkan tekanan darah responden lebih dari separuh mengalami penurunan tekanan darah. Pengalaman yang peneliti dapatkan dilapangan selama penelitian, penurunan tekanan darah dengan mengkonsumsi jus semangka ini lebih terlihat jelas secara teratur apabila responden atau individu tersebut menghindari makanan yang mengandung lemak seperti gajeboh dan gulai kambing.

\section{c. Pengaruh Jus Semangka terhadap Mean} Arteri Pressure (MAP) Pada Tekanan Darah Lansia Penderita Hipertensi di Wilayah Kerja Puskesmas Binjai Estate

Penelitian ini membandingkan Mean

Arteri Pressure (MAP) pada tekanan darah lansia penderita hipertensi pre dan post diberikan jus semangka. Sebelum diberikan jus semangka Mean Arteri Pressure (MAP) diukur terlebih dahulu dengan menggunakan tensi meter dan dihitung berdasarkan rumus yang sudah baku dan setelah itu responden diberikan jus semangka, Mean Arteri Pressure (MAP) diukur kembali dengan menggunakan alat dan rumus yang sama. Jumlah responden terdiri dari 28 orang yang berada di wilayah kerja Puskesmas Binjai Estate.

Berdasarkan hasil uji statistik dengan menggunakan Paired $t$-test menunjukkan ada pengaruh jus semangka terhadap Mean Arteri Pressure (MAP) pada tekanan darah lansia penderita hipertensi di wilayah kerja Puskesmas Binjai Estate tahun 2017 dengan nilai $\mathrm{p}=0,000$ dengan rata-rata sebelum diberikan jus semangka 119,304 dan sesudah diberikan pendidikan kesehatan 103,039.
Hasil penelitian ini senada dengan penelitian Gustomi, (2014) menunjukkan sebelum diberikan jus semangka tekanan darah responden prehipertensi $100 \%$ dan sesudah diberikan jus semangka tekanan darah responden sebagian besar mengalami tekanan darah normal 62,5\%. Hasil uji statistik menunjukan nilai $\mathrm{p}=0,00$ berarti $\mathrm{p}<0,05$ yang berarti ada pengaruh jus semangka terhadap tekanan darah pada penderita prehipetensi. Dengan demikian dapat dikatakan bahwa terdapat perbedaan antara sebelum dan sesudah dilakukan perlakuan sekaligus membuktikan bahwa jus semangka berpengaruh terhadap tekanan darah jus semangka mempunyai pengaruh yang signifikan dalam penurunan tekanan darah pada penderita prehipertensi, sehingga jus semangka sangat baik untuk mencegah penderita prehipertensi ke arah hipertensi grade 1 dan hipertensi grade 2.

Selain itu jus semangka juga dapat digunakan untuk alternatif lain dalam pengobatan herbal prehipertensi, hipertensi grade 1 dan hipertensi grade 2.Prevalensi hipertensi pada laki-laki lebih besar daripada perempuan dan diduga berkaitan dengan gaya hidup pria yang cenderung dapat meningkatkan tekanan darah. Berdasarkan jenis kelamin pada responden mayoritas perempuan yaitu sebanyak $64,3 \%$, hasil ini tidak sesuai dengan penelitian Mariani, (2007) menyatakan bahwa mayoritas lelaki yaitu sebanyak 26 orang $(55,3 \%)$ dibandingkan dengan subyek perempuan. Hasil penelitian ini tidak sesuai dengan penelitian lainnya diakibatkan karena hipertensi yang terjadi pada perempuan selain diakibatkan oleh gaya hidup ada faktor lain yang mempengaruhi yaitu faktor keturunan.

Beberapa penelitian menunjukkan bahwa makin tinggi umur seseorang maka makin tinggi pula tekanan darahnya. Penyakit hipertensi umumnya berkembang saat umur seseorang mencapai paruh baya (umur 40-60 tahun). Peluang terjadinya hipertensi meningkat dengan bertambahnya umur, terutama tekanan darah sistoliknya. Hal ini disebabkan oleh adanya perubahan struktur 
pada pembuluh darah. Persentase penderita hipertensi semakin meningkat pada setiap kelompok umur, hasil penelitian ini sesuai dengan pendapat diatas bahwa mayoritas responden yang menderita hipertensi berumur 50-65 tahun yaitu sebanyak 92,9\%.

MAP merupakan produk dari cardiac output dan total tahan perifer. Cardiac output cenderung meningkat di atas penurunan total tahanan ferifer, sehingga MAP seringkali sedikit meningkat. Sebaliknya pulse pressure terlihat meningkat akibat stroke volume dan kecepatan ejek stroke volume (Vander, 2001 dalam Fathoni, 2014).

Peningkatan cariac output terjadi akibat peningkatan denyut jantung dan sedikit peningkatan pada stroke volume. Peningkatan denyut jantung dihasilkan oleh perpaduan aktivitas parasimpatik di nodus SA dan peningkatan aktivitas simpatis. Peningkatan stroke volume terjadi terutama akibat peningkatan kontraktilitas ventrikel yang ditandai dengan peningkatan fraksi ejeksi dan diperantarai oleh saraf simpatis pada myocardium ventrikel. Disamping itu peningkatan stroke volume juga akibat dari sedikit peningkatan end diastolic volume sebesar 10\% (Vander, 2001 dalam Fathoni, 2014).

Semangka juga digemari orang karena banyak mengandung nilai gizi seperti vitamin $\mathrm{A}$ dan vitamin $\mathrm{C}$ serta kalium yang baik bagi kesehatan. Bagi penderita hipertensi, semangka dapat dikonsumsi sehingga bisa menetralisasi tekanan darah (Sandra, 2012).

Menurut Dr. Arturo Figueroa dan Profesor Bahram H. Arjmandi, semangka adalah sumber L-citrulline yang bisa dimakan, senyawa penting dalam memproduksi oksida nitrat, gas yang memperluas pembuluh darah. Setelah melakukan pengujian terhadap sejumlah relawan prahipertensi (garis batas tekanan darah tinggi) yang diberi diberi semangka, hasilnya terjadi peningkatan fungsi arteri, yang kemudian berefek menurunkan tekanan darah. Dr. Figueroa mengatakan penemuan ini menunjukkan bahwa semangka memiliki efek dilatasi (memperlebar pembuluh darah) dan satu yang bisa mencegah prahipertensi meningkat menjadi hipertensi, faktor risiko utama serangan jantung dan stroke.

Peneliti berpendapat penurunan tekanan darah tergantung pola hidup dan pola makan yang baik serta banyaknya semangka yang dimakan, jika konsumsi semangka banyak maka penurunan tekanan darah akan banyak dan jika konsumsi semangka sedikit maka penurunan tekanan darahnya juga sedikit.

\section{KESIMPULAN}

1. Mean Arteri Pressure (MAP) pada lansia penderita hipertensi di wilayah kerja puskesmas Binjai Estate sebelum diberikan jus semangka dengan nilai ratarata (mean) 119,304 mmHg.

2. Mean Arteri Pressure (MAP) pada lansia penderita hipertensi di wilayah kerja puskesmas Binjai Estate sesudah diberikan jus semangka dengan nilai ratarata (mean) 103,039 mmHg.

3. Ada pengaruh jus semangka terhadap Mean Arteri Pressure (MAP) pada lansia penderita hipertensi di wilayah kerja puskesmas Binjai Estate dengan nilai $p$ value $=0,000$ maka Ha diterima dan Ho ditolak.

\section{SARAN}

1. Bagi Responden

Bagi responden diharapkan dapat melanjutkan untuk mengkonsumsi jus semangka lebih rutin selama 7 hari semangka dengan berat 250 gram/hari, akan tetapi perlu mengontrol tekanan darah agar tidak terjadi hipotensi secara mendadak dan perlu memperbaiki pola hidup yang baik

2. Bagi Pendidikan Keperawatan

Bagi pendidikan keperawatan agar lebih memproritaskan pendidikan tentang obat herbal bagi perawat khususnya manfaat buah-buahan.

3. Bagi Peneliti Selanjutnya

Peneliti selanjutnya diharapkan dapat melakukan penelitian lebih lanjut tentang pengaruh jus semangka terhadap Mean Arteri Pressure (MAP) Pada Tekanan 
Darah Lansia Penderita Hipertensi dengan lamanya jadwal pemberian terapi jus semangka dan jadwal mengkonsumsinya.

\section{DAFTAR PUSTAKA}

Apriyanti. (2011). Meracik Sendiri Obat \& Menu Sehat Bagi Penderita Darah Tinggi. Yogyakarta: Baru Press.

Ardiansyah, M. (2012). Medikal Bedah. Jogjakarta: Diva Press.

Arturo. (2012). Turunkan Hipertensi dengan Semangka. Diakses dari http://dokternasir.web.id/2010/10/tur unkan-tekanan-darah-tinggi-dengansemangka.

Ashari, S. (2006). Hortikultura Aspek Budidaya. Jakarta: Universitas Indonesia.

Casey, A., \& Benson, H. (2012). Menurunkan Tekanan Darah. Jakarta: PT Bhuana Ilmu Populer.

Damayanti. (2009). Kajian Pelaksanaan Kemitraan dalam Meningkatkan Pendapatan Antara Petani Semangka di Kabupaten Kebumen Jawa Tengah dengan CV. Bimandiri. IPB Press. Bogor.

Duljapar dan Setyowati. (2000). Petunjuk Bertanam Semangka Sistem Turus. Cetakan ke-1. Jakarta: Penebar Swadaya.

Elisa. (2012). Bebas Hipertensi dengan Jus. Bandung : Niaga Swadaya

Fathoni. (2014). Penurunan Tekanan Darah dan Mean Arterial Pressure (MAP) Pasca Bersepeda Luar Ruangan dan Beberapa Faktor yang Berhubungan. Jakarta: Thesis Fakultas Kedokteran Universitas Indonesia Program Studi Ilmu Kedokteran Olahraga

Fridalni, N., \& Sapardi, V. S. (2013, September 2-16). Pengaruh Pemberian Jus Semangka (Cilitrus Vulgaris Schrad) Terhadap Penurunan Tekanan Darah Lansia Dengan Riwayat Hipertensi Di Kota Padang.
Gustomi. (2014). Jus Semangka Menurunkan Tekanan Darah Pada Pasien Prehipertensi. Gresik : Skripsi FIK Universitas Gresik

Guyton AC \& Hall JE. Buku ajar fisiologi kedokteran:Ed.9.Editor alih bahasa Indonesia: Irawati. Jakarta: EGC

Irma. (2009). Pengaruh Buah Semangka (Citrullus vulgaris Schard. Fructus) terhadap Tekanan Darah Normal Laki-laki Dewasa. Bandung: Universitas Kristen Maranatha

Kalie, M. B. (2006). Bertanam Semangka. Penebar Swadaya.

Komaling, J. K., Suba, B., \& Wongkar, D. (2013, Agustus). Hubungan Mengonsumsi Alkohol Dengan Kejadian Hipertensi Pada Laki-Laki Di Desa Tompasobaru II Kecamatan Tompasobaru Kabupaten Minahasa Selatan. ejurnal keperawatan, 1 .

Lapian, E. L., Malonda, N. S., \& Kapantow, G. (2014). Hubungan Antara Konsumsi Alkohol Dengan Kejadian Hipertensi Pada Laki-Laki Usia 2565 Tahun Di Desa Kapoya Kecamatan Tareran Suluun Kabupaten Minahasa Selatan. Kesehatan Masyarakat.

Maidelwita. (2011). Faktor Resiko Terjadinya Hipertensi Lansia. Jurnal $M N M$.

Mariani, 2007. Pengaruh Pemberian Jus Pepaya , Jus Semangka dan Jus Melon Terhadap Penurunan Tekanan Darah Sistolik dan Diastolik. Semarang : Skripsi PRODI Ilmu Gizi Univ. Dipenogoro

Nisa. (2012). Ajaibnya Terapi Herbal Tumpas Penyakit Darah Tinggi. Jakarta: Dunia Sehat.

Notoatmodjo, S. (2012). Metodologi Penelitian Kesehatan . Jakarta: Rineka Cipta.

Riskesdas. (2013). Prevalensi Hipertensi. Jakarta : Kementrian Kesehatan Repuplik Indonesia.

Sandra, A. A. (2012). Pengaruh Pemberian Bokashi terhaadap Pertumbuhan dan 
Hasil Tanaman Semangka (Citrullus Vulgaris L). Pertenakan UIN.

Sastroasmoro, S., \& Ismael, S. (2016). Dasar-Dasar Metodologi Penelitian Klinis Edisi ke-5. Jakarta.

Sinubu, R. B., Rondonuwu, R., \& Onibala, F. (2015, Mei). Hubungan Beban Kerja Dengan Kejadian Hipertensi Tenaga Pengajar Di SMAN 1 Amurang Kabupaten Minahasa Selatan. $e$ Journal Keperawatan, 3.

Sobir, \& Siregar, F. D. (2010). Budidaya Semangka Panen 60 hari. Penebar Swadaya.

Soeria, A. (2013). 101 Resep Ampuh Sembuhkan Asam Urat, Hipertensi \& Obesitas. Jawa Timur: Araska Publisher.

Suiraoka, I. (2016). Penyakit Degeneratif. Yogyakarta: Nuha Medika.

Suriana dan Shobariani. 2013. Ensiklopedia Tanaman Obat. Malang : Rumah Ide

Susilo, W. H., Aima, H., \& Suprapti, F. (2014). Biostatika Lanjut dan Aplikasi Riset. (T. Ismail, Ed.) Jakarta.

Suwandi, M. M. (2013). Pengaruh Mengkonsumsi Pisang Ambon Terhadap Penurunan Tekanan Darah Pada Lansia Penderita Hipertensi Di Panti Werdha Mojopahit Kabupaten Mojokerto. Keperawatan.

Triyanto, E. (2014). Pelayanan Keperawatan Bagi Penderita Hipertensi Secara Terpadu. Yogyakarta: Graha Ilmu.

Wade, C. (2016). Mengatasi Hipertensi. Bandung: NUANSA CENDIKIA.

World Health Organization. (2013). A Global Brief on Hypertension-Sillent Killer, Global Public 